\title{
Fours à cade, fours à poix : de l'étude architecturale à la distillation expérimentale
}

Ada Acovitsioti-Hameau, Philippe Hameau et Thierry Rosso

\section{(2) OpenEdition}

Édition électronique

URL : https://journals.openedition.org/tc/593

DOI : $10.4000 /$ tc. 593

ISSN : 1952-420X

Éditeur

Éditions de l'EHESS

\section{Édition imprimée}

Date de publication : 1 mars 1995

ISSN : 0248-6016

\section{Référence électronique}

Ada Acovitsioti-Hameau, Philippe Hameau et Thierry Rosso, « Fours à cade, fours à poix : de l'étude architecturale à la distillation expérimentale », Techniques \& Culture [En ligne], 22 | 1995, mis en ligne le 30 décembre 2005, consulté le 29 septembre 2022. URL : http://journals.openedition.org/tc/593 ; DOI : https://doi.org/10.4000/tc.593

Ce document a été généré automatiquement le 29 septembre 2022.

Tous droits réservés 
Fours à cade, fours à poix : de l'étude architecturale à la distillation expérimentale

Ada Acovitsioti-Hameau, Philippe Hameau et Thierry Rosso 